\title{
Urinary excretion of leucine aminopeptidase in pregnancy
}

\author{
D. P. MULLAN ${ }^{1}$ \\ From the United Sheffield Hospitals
}

SYNOPSIS This paper describes enzyme studies in normal and abnormal pregnancy. Urinary leucine ${ }_{i}^{\frac{8}{0}}$ aminopeptidase (L.A.P.) excretion remained relatively low throughout normal single pregnancy.. Urinary L.A.P. excretion was, however, raised towards term in four out of five cases of multiple ${ }_{\sigma}^{+}$ pregnancy, but in one patient the predelivery urinary L.A.P. was not raised, and the second twin尺 in this case died shortly after delivery with gross congenital abnormalities.

Urinary L.A.P. was also investigated in 'high-risk' patients. One such patient had excessive lossof this enzyme throughout pregnancy, and in the discussion it is suggested that this could be due to excessive loss of oxytocinase in the urine.

Patients with toxaemia were assessed on the basis of foetal survival and the maximum 24-hour\% pre-delivery urinary levels of leucine aminopeptidase. This urinary value could not be used to predict. foetal outcome, but rose to over $120 \mathrm{mg}$. beta-naphthylamine per 24 hours in the presence of frank proteinuria. If intrauterine death occurred, the urinary L.A.P. value fell gradually. Urinary L.A.P. was also elevated in essential hypertension towards term, but in these patients there was no gross proteinuria.

A number of investigators have been interested in enzyme changes in pregnancy and the general object has been to see if any particular pattern of change is useful in the diagnosis of the complications of pregnancy. Most workers have concentrated on enzyme changes in the serum, and the urine has not been so well studied.

Serum leucine aminopeptidase activity rises during pregnancy (Green, Tsou, Bressler, and Seligman, 1955; Arst, Manning, and Delp, 1959; Siegel, 1959; Bressler and Forsyth, 1959; Lewis 1962), and serum levels of this enzyme return to normal six to eight weeks after delivery. Leucine aminopeptidase activity can easily be measured in the urine (Goldbarg, Pineda, and Rutenburg, 1959), and in this study the activity of this urinary enzyme has been measured in both normal and abnormal pregnancy. Preliminary results are recorded, and in the discussion other possible lines of research are suggested.

\section{METHOD}

Measurements of L.A.P. activity in serum and urine were made in normal and multiple pregnancy, in severe and mild toxaemia, in essential hypertension, and in a

${ }^{1}$ Now in receipt of a research award from the United Sheffield Hospitals Endowment Fund. group of 'high-risk' patients with a past history of abor-3 tions, intrauterine death, or premature delivery (Table I). Tables II, III, and IV include clinical details in patients? with mild, moderate, and severe toxaemia, and Table V gives the urinary L.A.P. levels in all the patients studied.?

Serum was obtained from fasting patients. Urine was collected for 24 hours, and an aliquot was dialysed in . order to remove enzyme inhibitors. Leucine amino- $\widehat{\varrho}$ peptidase activity was determined by the method of 3 Goldbarg et al. (1959) which uses l-leucyl-beta naphthyl-o amide as substrate. This is hydrolysed to yield betanaphthylamine, which is then diazotized and finallyo coupled with $\mathrm{N}$-(l-naphthyl) ethylenediamine to yield a stable blue dye. The optical density of the azo dye was N measured with an EEL colorimeter. The relationship between optical density and beta-naphthylamine concen- $\mathrm{N}$ tration was linear over a range of 3 to $60 \mu \mathrm{g}$. per $\mathrm{ml}$.

UNITS

UNITS OF MEASUREMENT OF LA.P. Serum LA.P activity is expressed in terms of the number of micrograms of ${ }^{\circ}$ beta-naphthylamine liberated from $1 \mathrm{ml}$. of a $2 \%$ solution of the serum (Harkness, Roper, Durant, and Miller, $\stackrel{\mathbb{\Phi}}{\mathbb{\Phi}}$ 1960). Urinary L.A.P. activity represents the total urinary excretion of this enzyme in 24 hours. These urine units are defined as the number of milligrams of beta-naphthy- 
TABLE I

HIGH-RISK PATIENTS

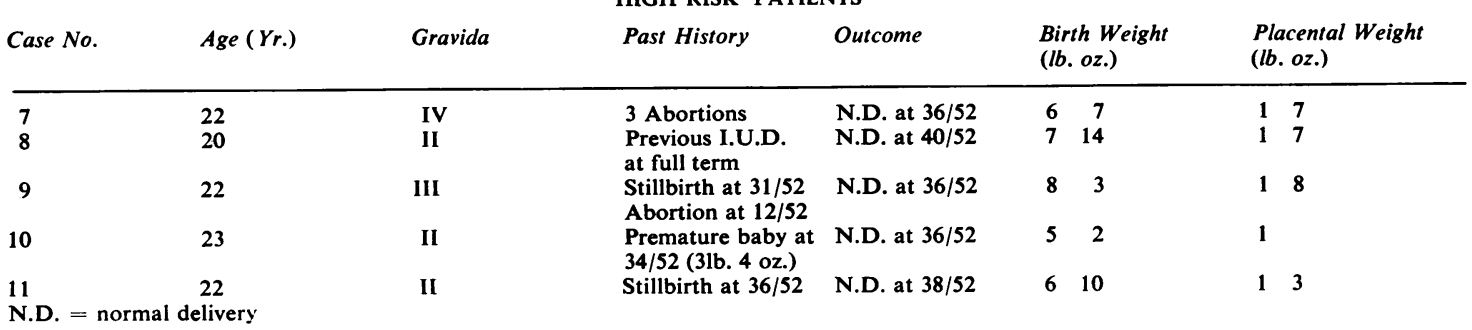

TABLE II

MILD CASES OF TOXAEMIA WITHOUT PROTEINURIA

\begin{tabular}{|c|c|c|c|c|c|c|}
\hline Case No. & Age ( $Y r)$. & Gravida & $\begin{array}{l}\text { Blood Pressure } \\
(\mathrm{mm} . \mathrm{Hg})\end{array}$ & Outcome & $\begin{array}{l}\text { Birth Weight } \\
\text { (lb. oz.) }\end{array}$ & $\begin{array}{l}\text { Placental Weight } \\
\text { (lb. oz.) }\end{array}$ \\
\hline $\begin{array}{l}25 \\
26 \\
27\end{array}$ & $\begin{array}{l}14 \\
23 \\
39\end{array}$ & III & $\begin{array}{l}150 / 100 \\
150 / 100 \\
150 / 90\end{array}$ & $\begin{array}{l}\text { N.D. at } 40 / 52 \\
\text { N.D. at } 39 / 52 \\
\text { N.D. at } 39 / 52\end{array}$ & $\begin{array}{rr}7 & 10 \\
7 & 8 \\
6 & \end{array}$ & $\begin{array}{ll}1 & 7 \\
1 & 6 \\
1 & 8\end{array}$ \\
\hline
\end{tabular}

TABLE III

MODERATE OR SEVERE TOXAEMIA WITH PROTEINURIA AND FOETAL SURVIVAL

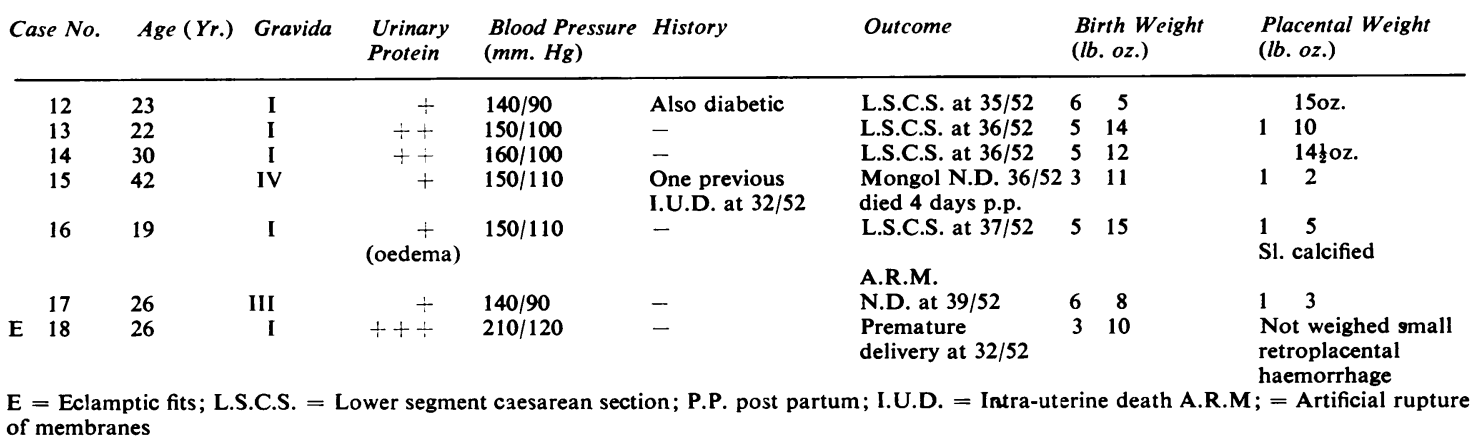

TABLE IV

SEVERE TOXAEMIA WITH INTRAUTERINE DEATH

\begin{tabular}{|c|c|c|c|c|c|c|c|c|c|}
\hline \multicolumn{2}{|c|}{ Case No. } & Age $(Y r)$. & Gravida & $\begin{array}{l}\text { Urinary } \\
\text { Protein }\end{array}$ & $\begin{array}{l}\text { Blood Pressure } \\
(\mathrm{mm} . \mathrm{Hg})\end{array}$ & History & Outcome & $\begin{array}{l}\text { Birth Weight } \\
\text { (lb. oz.) }\end{array}$ & $\begin{array}{l}\text { Placental Weight } \\
\text { (oz.) }\end{array}$ \\
\hline & 19 & 24 & III & +++ & $170 / 120$ & 1 stillbirth & $\begin{array}{l}\text { Stillbirth Breech } \\
\text { at } 32 / 52\end{array}$ & 113 & $6 \frac{1}{2}$ \\
\hline & 20 & 23 & I & $++t$ & $160 / 110$ & - & $\begin{array}{l}\text { Intrauterine death } \\
\text { N.D. at } 29 / 52\end{array}$ & 2 & 11 \\
\hline & 21 & 22 & I & $+t+$ & $180 / 110$ & - & $\begin{array}{l}\text { I.U.D. A.R.M. } \\
\text { N.D. at 34/52 }\end{array}$ & $\begin{array}{l}2 \underset{\text { (Macerated) }}{9} \\
\text { (Macer }\end{array}$ & $6 \frac{1}{2}$ \\
\hline $\mathbf{E}$ & 22 & 21 & II & $+t+$ & $180 / 110$ & 1 abortion & Stillbirth at $35 / 52$ & 412 & 15 \\
\hline & 23 & 30 & III & +1 & $140 / 105$ & - & $\begin{array}{l}\text { I.U.D. } \\
\text { N.D. at } 33 / 52\end{array}$ & $\begin{array}{l}213 \\
\text { (Macerated) }\end{array}$ & $\begin{array}{l}11 \frac{1}{2} \\
\text { (areas of infarction) }\end{array}$ \\
\hline & 24 & 24 & III & ++ & $160 / 110$ & 1 abortion & $\begin{array}{l}\text { Stillbirth } \\
\text { Breech at } 34 / 52\end{array}$ & 34 & $\begin{array}{l}15 \frac{1}{2} \\
\text { (extensive infarcts) }\end{array}$ \\
\hline
\end{tabular}

lamine liberated by the entire 24-hour volume of urine (Goldbarg et al. 1959).

Urine units $=10 \mathrm{NV}$ where

$\mathbf{N}=\mu \mathrm{g}$. of beta-naphthylamine liberated by $0.1 \mathrm{ml}$. of urine.

and $\mathrm{V}=24$-hour volume of urine (L).

Harkness et al. (1960) found that the mean serum L.A.P. $\quad \times 3$. 


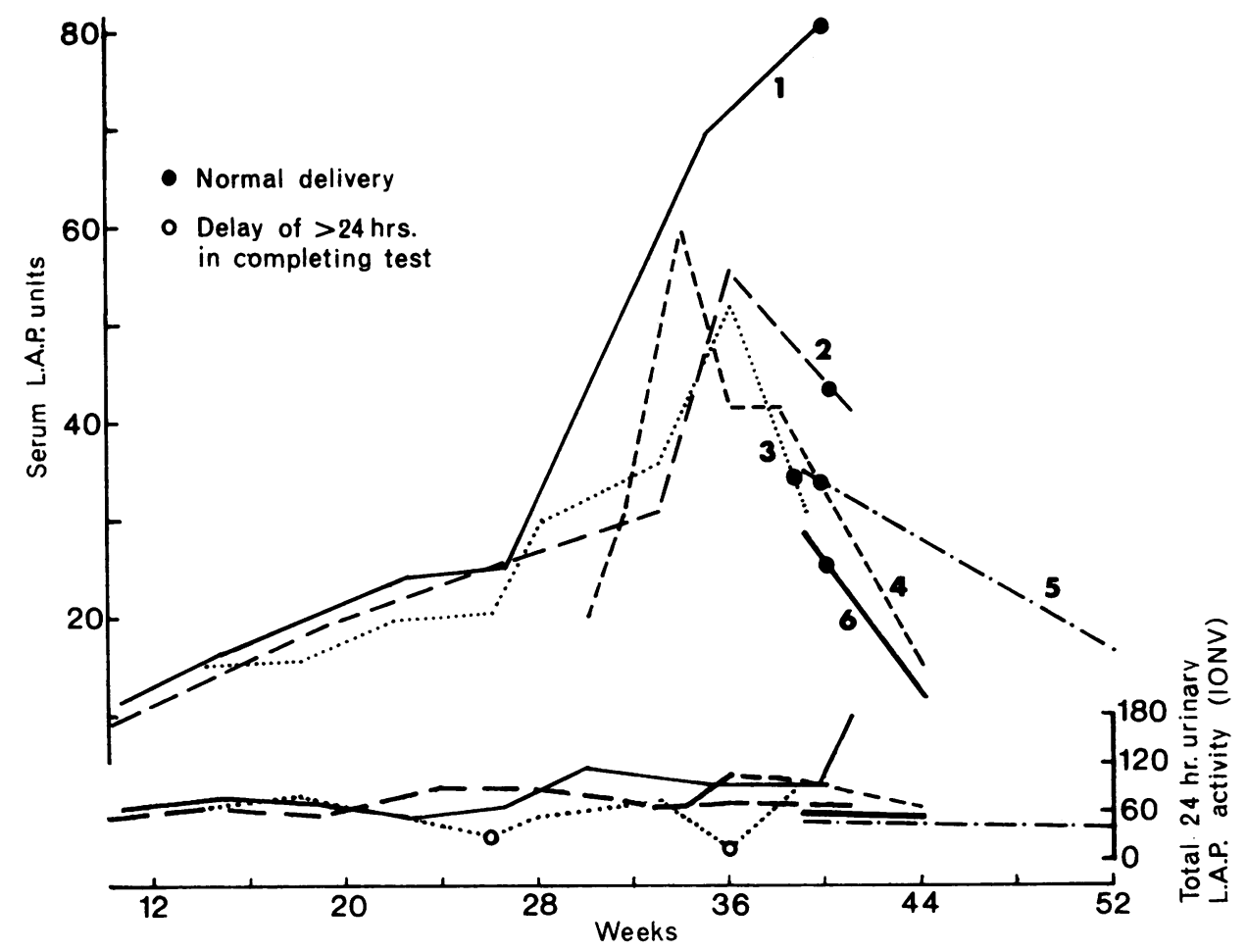

FIG. 1.

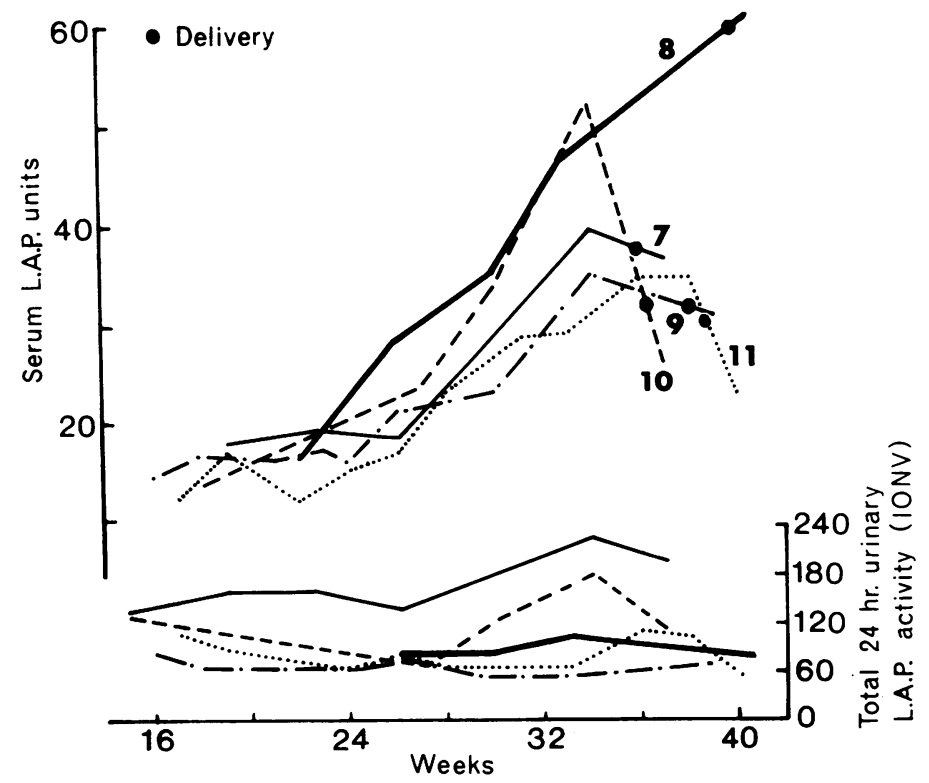

FIG. 1. Leucine aminopeptidase activity in normal single pregnancy (cases 1 to 6).

FIG. 2. Serial L.A.P. activity in 'high risk' patients (cases $7,8,9,10$, and 11). 
RESULTS

Figure 1 shows serum and urinary L.A.P. levels in normal single pregnancy. In spite of an increasing level of serum L.A.P. during pregnancy, the urinary excretion of this enzyme remains relatively low, i.e., below $120 \mathrm{mg}$. beta-naphthylamine in 24 hours. As in case 1 , there may be a transient post-partum increase in urinary L.A.P., but this later returned to normal. It should be noted (case 3) that delay in completing the enzyme test on the urine can give a low value.

In four cases of multiple pregnancy the urinary excretion of L.A.P. towards term was higher than in single pregnancy. All the babies of these four patients survived and were normal. However, in one patient (case C) the pre-delivery urinary L.A.P. value was not raised, and it is of interest that the second twin in this case had a meningocoele, spina bifida and exomphalos, and died shortly after a breech delivery.

Figure 2 demonstrates serial enzyme changes in five 'high-risk' patients. As can be seen, the urinary L.A.P. excretion in case 7 was high throughout pregnancy. At no stage was there any proteinuria, and careful follow up of this patient showed that there was no evidence of renal disease. Three months after delivery the serum L.A.P. was normal at $\mathbf{1 2 . 0}$ units, and the 24-hour urinary L.A.P. was also normal at $63 \mathrm{mg}$. beta-naphthylamine. There was no excess of pus cells in the urine and culture was sterile.

Table $\mathrm{V}$ shows the average maximum pre-delivery 24-hour urinary L.A.P. and range of values in mild, moderate, and severe toxaemia of pregnancy, and also in essential hypertension (groups 4 to 7 ). In mild toxaemia the urinary value was low and normal. In three patients with familial essential hypertension without proteinuria, the urinary L.A.P. values were elevated. However, patients with toxaemia and proteinuria (groups 6 and 7) had even higher pre-

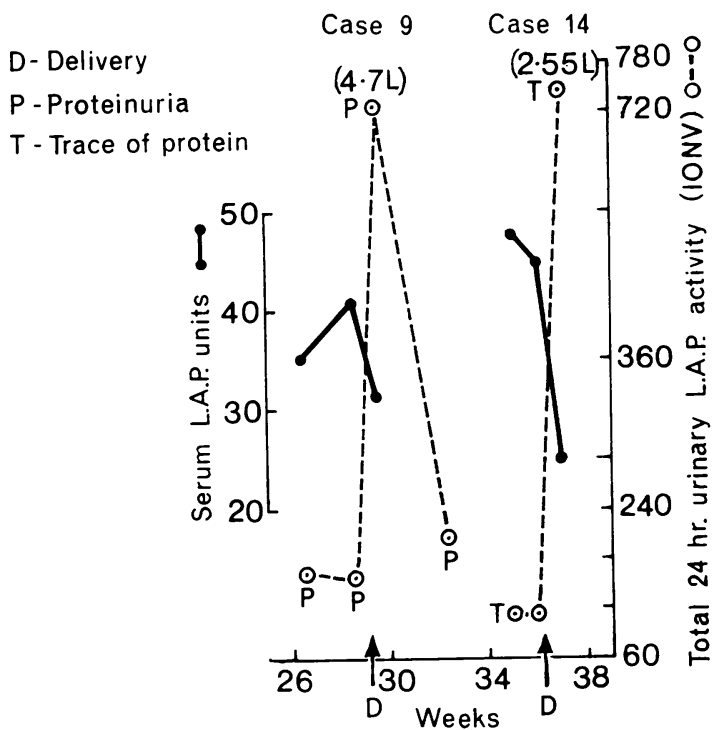

FIG. 3. Post-partum 'enzyme diuresis' in severe toxaemia (cases 9 and 14).

delivery levels of urinary L.A.P., and in these cases it was found that when frank proteinuria developed the urinary L.A.P. rose to a value of over $120 \mathrm{mg}$. beta-naphthylamine in 24 hours. As can be seen, the average maximum pre-delivery 24-hour urinary value in groups 6 and 7 is almost the same, and therefore this value cannot be used to predict foetal survival in severe cases of toxaemia. It was also noted that if intrauterine death occurred then the urinary L.A.P. fell gradually and foetal delivery was delayed. The urinary L.A.P. values were low in two cases of intrauterine death without toxaemia (group 8). It is of interest that one patient in group 6 with a high pre-delivery urinary L.A.P. level of $336 \mathrm{mg}$. beta-naphthylamine per 24 hours had a mongol baby with congenital heart disease who died

TABLE V

PREDELIVERY 24-HOUR URINARY LEUCINE AMINOPEPTIDASE

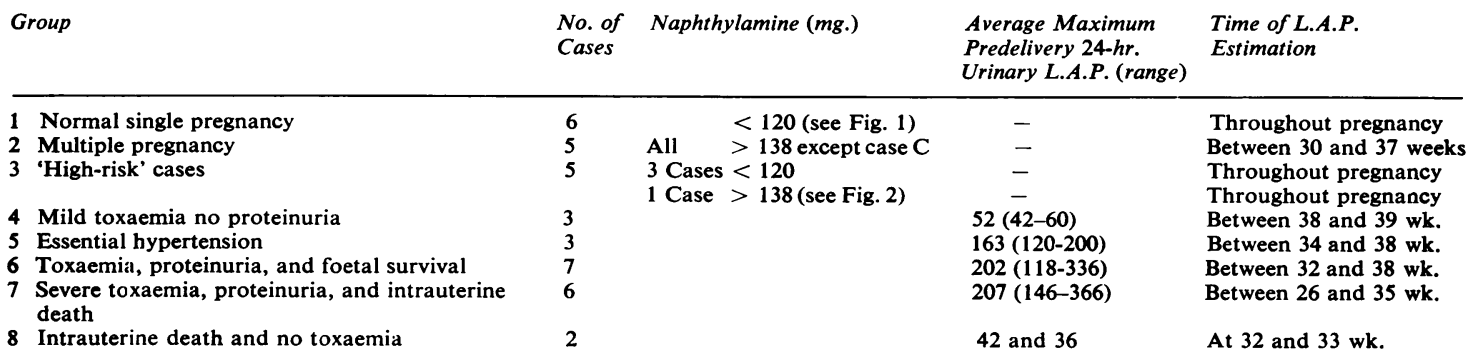


four days after delivery. Another patient in group 6 rapidly became pregnant again; she did not develop toxaemia during her second pregnancy and her pre-delivery urinary L.A.P. excretion was much lower.

Finally, Fig. 3 demonstrates the massive 'enzyme diuresis' that can occur in the immediate post-partum period. In case 14 the post-partum urinary L.A.P. was estimated when the 24-hour urine was 2.551 ., and in case 20 the urinary enzyme estimation was made when the 24-hour urine was 4.7 litres.

\section{DISCUSSION}

The first observation that was made in this study was that, in spite of increasing levels of serum L.A.P., the kidney in normal single pregnancy does not excrete an excessive amount of this enzyme. However, before delivery, four patients with multiple pregnancy had raised levels of urinary leucine aminopeptidase. In this connexion, it has already been shown that the activities of cystine aminopeptidase and L.A.P. tend to be higher in twin as compared with single pregnancies (Miller, Naor, Milkovich, and Schmidt, 1964).

The substrate used for the L.A.P. test is also hydrolysed by oxytocinase (Page, Titus, Mohun, and Glendening, 1961 ; Glendening, Titus, Schroeder, Mohun, and Page, 1965), and therefore the raised urinary L.A.P. in case 7, and possibly in case 10 (Fig. 2), could be due to increased oxytocinase excretion in the urine. The urine has to be considerably concentrated to measure urinary oxytocinase and the values obtained may only be approximate (Glendening, 1966). However, work is now in progress to see if it is possible to demonstrate that some high-risk patients are oxytocinase leakers, and it may be possible to show that such patients excrete an excessive amount of this enzyme in successive pregnancies.

Furthermore, there is good evidence that oxytocinase is derived from the placenta (Page et al. 1961), and in future studies of placental insufficiency it will be important to correlate serial enzyme changes with other parameters, such as the excretion of urinary pregnandiol (Russell, Dewhurst, and Blakey, 1960).
Severe cases of toxaemia have been assessed on the basis of the maximum 24-hr. pre-delivery urinary leucine aminopeptidase. Although more information is required, it seems clear that this value cannot be used to predict foetal outcome. However, heavy proteinuria and an increased urinary L.A.P. form a sinister sign in severe toxaemia, and if the urinary L.A.P. later falls then intrauterine death has probably occurred. Likewise, Babuna and Yenen (1966) showed that in severe toxaemia decreasing levels of serum oxytocinase indicated diminishing placental function and impending foetal death.

The toxaemic patients in this study have been followed up. Repeat urinary L.A.P. estimations were normal, and urine culture was sterile in each case. Urinary L.A.P., like other enzymes, can be raised in patients with renal damage and pyelonephritis (Bergmann and Scheler, 1964). It was felt that if, after delivery the urinary L.A.P. failed to return to a normal low level, then underlying pyelonephritis should be considered.

I wish to thank the consultant staff at the Jessop Hospital for Women for allowing me to investigate their patients, Mrs. R. Taylor for collecting the specimens, Dr. Arthur Jordan for allowing me to use the laboratory facilities at the Royal Hospital, Sheffield, and Dr. C. E. Davies for his encouragement throughout these studies.

\section{REFERENCES}

Arst, H. E., Manning, R. T., and Delp, M. (1959). Amer. J. med. Sci., 238, 598.

Babuna, C., and Yenen, E. (1966). Amer. J. Obstet. Gynec., 95, 925. Bergmann, H., and Scheler, F. (1964). Klin. Wschr., 42, 275.

Bressler, R., and Forsyth, B., R. (1959). New Engl. J. Med., 261, 746.

Glendening, M. B., Titus, M. A., Schroeder, S. A., Mohun, G., and Page, E. W. (1965). Amer. J. Obstet. Gynec., 92, 814.

(1966). Personal communication.

Goldbarg, J. A., Pineda, E. P., and Rutenburg, A. M. (1959). Amer. J. clin. Path., 32, 571.

Green, M. N., Tsou, K. C., Bressler, R., and Seligman, A. M. (1955) Arch. Biochem., 57, 458.

Harkness, J., Roper, B. W., Durant, J. A., and Miller, H. (1960). Brit. med. J., 1, 1787.

Lewis, J., Jr. (1962). Amer. J. Obstet. Gynec., 84, 1407.

Miller, Z. B., Naor, E., Milkovich, L., and Schmidt, W. M. (1964) Obstet and Gynec., 24, 707.

Page, E. W., Titus, M. A., Mohun, G., and Glendening, M. B. (1961) Amer. J. Obstet. Gynec., 82, 1090.

Russell, C. S., Dewhurst, C. J., and Blakey, D. H., (1960). J. Obstet. Gynaec. Brit. Emp., 67, 1.

Siegel, I. A. (1959). Obstet. and Gynec., 14, 488. 